\title{
Biological Monitoring of Occupational Exposure to Contraceptive Drugs
}

\author{
Magdy Youssef SHAMY*, Osama El-Sayed SOLIMAN, \\ Hassan Ahmed OSMAN and Ragaa Mohammed EL-GAZZAR.
}

\author{
High institute of Public Health, 165 El Horreya Avenue, Hadara, \\ Alexandria, Egypt
}

(Received November 20, 1995 and in revised form February 20, 1996)

\begin{abstract}
The present study was carried out for screening some biochemical changes due to occupational exposure to contraceptive drugs. It included 18 male workers and 22 female workers involved in the manufacture of contraceptive pills and 34 female workers manufacturing contraceptive ampoules. The levels of some sex hormones and gonadotropins were evaluated. Some parameters of blood picture, blood coagulation, liver and kidney functions, lipid profile and trace elements metabolism were assessed. Results were compared with those of a control group composed of 19 males and 27 females. Increased levels of estrogen among exposed workers was the main finding. It has been attributed to liver rather than pituitary dysfunction. A less atherogenic lipid profile has also been found. Referral to preventive measures has been recommended.
\end{abstract}

Key words: Contraceptive drugs - Sex hormones - Gonadotropins - Liver function Lipid profile

\section{INTRODUCTION}

Sex hormones have been employed therapeutically for a number of years in contraceptive preparations and for the treatment of menstrual and menopausal disorders ${ }^{1)}$. The side effects of oral contraceptives have been investigated in depth ${ }^{2}$.

During manufacture of contraceptive drugs, the working environment may be contaminated. Airborne particles of sex hormones may be absorbed through the skin, ingested or inhaled. They may accumulate and reach relatively high levels even if their absorption is intermittent. Consequently, repeated absorption of small amounts may be detrimental to health ${ }^{3)}$.

The effects of exposure to estrogen and progesterone in the work place have been recognized for many years. Feminization in men and masculinization or

\footnotetext{
* to whom correspondence must be addressed.
} 
menstrual disorders in women have been $\operatorname{seen}^{4)}$. Some attention has been given to the risk of developing neoplastic disease ${ }^{5)}$. But few are the studies screening the biochemical and hematological changes due to occupational exposure to such drugs. This is what the present study tries to elucidate.

\section{Materials AND Methods}

This work was performed in one of the companies producing contraceptive drugs in Cairo, Egypt. The factory comprised a "pills production section" with etbinyl estradiol and levononorgestrel as active ingredients; and an "ampoule production section" with medroxyprogesterone as active ingredient. In the latter section, exposure was said to be more intense ${ }^{5}$. However, no data are available concerning the concentrations of these compounds in the air of work place. The manufacturing steps were the same in both sections and included dry blending, wet granulation with organic solvents, drying, sieving and final dry blending. Therefore, the routes of exposure are both by skin absorption and inhalation. Male workers $(n=18)$ were randomly selected from the pills production section. Only post menopausal females who stopped using contraceptives for at least 2 years were included in the study to minimize the effect of the non occupational exposure. They were chosen from the pills production section $(n=22)$ and from the ampoules production section $(n=34)$. A matched control group has been selected from the administrative departments of the same factory. It included 19 males and 27 females.

A $10 \mathrm{ml}$ fasting blood sample was obtained from each examined subject the last working day at the end of the subject's shift. Blood samples of subjects and matched controls were collected at the same time of the day. A part of the blood was taken on EDTA for the hematological investigations. The rest was left to clot, centrifuged and serum separated for the biochemical analyses.

The hematological investigations included a complete blood picture: erythrocytes count (RBCs), total leucocytic count (WBCs), differential count, hematocrit value, clotting and bleeding times. These were done according to standard methods ${ }^{6}$. Commercial kits were used for the determination of hemoglobin levels and prothrombin time (Biomerieux kits).

\section{The biochemical analysis included}

- The levels of sex hormones: estrogen, progesterone and testosterone and the levels of gonadotropins: follicle stimulating hormone (FSH), luteinizing hormone (LH) and luteotropic hormone or prolactin (LTH). All hormones were assessed by quantitative-enzyme-immunoassay kits.

- Fasting blood sugar (FBS), transaminases (ALT and AST) serum creatinine, total cholesterol, triglyceride, high and low density lipoproteins cholesterol (HDLCh and LDLCh). Commercial kits were also used for these determinations. 
- Trace element analysis including the levels of calcium, manganese, iron, copper zinc and magnesium. Atomic absorption spectrophotometry (Shimadzu AA680) was used for that purpose ${ }^{7)}$.

In the statistical analysis, comparison was done between exposed and non exposed groups. Student's $t$-test was used and significance was checked at either 0.05 or 0.01 level.

\section{RESULTS}

The mean levels of age and duration of exposure among workers exposed to contraceptive drugs and their controls are presented in Table 1. The mean age of female workers and consequently their duration of exposure were found to be higher than that of males due to the fact that they were all chosen post menopausal. But females manufacturing either pills or ampoules were very close in their age and duration of exposure. Also the mean age of both exposed males and females was close to their controls.

The mean levels of sex hormones and gonadotropins in blood of workers exposed to contraceptive drugs and their controls are shown in Table 2. For the sex hormones, the mean levels of testrogen were found to be increased significantly $(\mathrm{p}<0.05,0.01)$ among exposed workers of both sexes. The mean levels of testosterone were significantly lower $(\mathrm{p}<0.01)$ than that of controls only among male workers. No statistically significant changes has been detected in the mean levels of progesterone between exposed workers and control subjects. Concerning the gonadotropins: FSH, LH and LTH, none of them showed any significant deviation from controls neither among males nor among females exposed to contraceptive drugs.

Table 1. Mean levels of age and duration of exposure among workers exposed to contraceptive drugs and their controls.

\begin{tabular}{|c|c|c|c|c|c|c|}
\hline & \multirow[b]{4}{*}{$\mathrm{n}=$} & \multicolumn{2}{|c|}{ Males } & \multicolumn{3}{|c|}{ Females } \\
\hline & & \multirow[t]{2}{*}{ Exposed } & \multirow[t]{2}{*}{ Controls } & \multicolumn{2}{|c|}{ Manufacturing } & \multirow[t]{2}{*}{ Controls } \\
\hline & & & & Pills & Ampoules & \\
\hline & & 18 & 19 & 22 & 34 & 27 \\
\hline \multirow[t]{2}{*}{ Age (years) } & $\bar{X}$ & 35.4 & 36.2 & 52.3 & 51.7 & 51.9 \\
\hline & SD & 4.6 & 5.1 & 4.9 & 5.1 & 3.9 \\
\hline \multirow[t]{2}{*}{ Duration (years) } & $\bar{x}$ & 16.3 & - & 27.6 & 26.9 & - \\
\hline & SD & 3.7 & - & 4.5 & 6.1 & - \\
\hline
\end{tabular}

$* \mathrm{p}<0.01$

$* * \mathrm{p}<0.05$, exposed group versus control group 
Table 2. Mean levels of sex hormones and gonadotropins in blood of workers exposed to contraceptive drugs and their controls.

\begin{tabular}{|c|c|c|c|c|c|c|}
\hline & \multirow[b]{4}{*}{$\mathrm{n}=$} & \multicolumn{2}{|c|}{ Males } & \multicolumn{3}{|c|}{ Females } \\
\hline & & \multirow[t]{2}{*}{ Exposed } & \multirow[t]{2}{*}{ Controls } & \multicolumn{2}{|c|}{ Manufacturing } & \multirow[t]{2}{*}{ Controls } \\
\hline & & & & Pills & Ampoules & \\
\hline & & 18 & 19 & 22 & 34 & 27 \\
\hline \multicolumn{7}{|l|}{ Sex hormones: } \\
\hline Estrogen & $\overline{\mathrm{X}}$ & $46.72 * *$ & 30.97 & $58.23 * *$ & $54.61 * *$ & 39.46 \\
\hline$(\mathrm{pg} / \mathrm{ml})$ & SD & 10.93 & 16.71 & 14.16 & 9.08 & 9.53 \\
\hline Progesterone & $\bar{X}$ & 0.51 & 0.38 & 0.64 & 0.60 & 0.33 \\
\hline$(\mathrm{ng} / \mathrm{ml})$ & SD & 0.17 & 0.53 & 1.43 & 0.19 & 1.00 \\
\hline Testosterone & $\overline{\mathrm{X}}$ & $5.42 * *$ & 8.13 & 0.46 & 0.61 & 0.55 \\
\hline$(\mathrm{pg} / \mathrm{ml})$ & SD & 1.81 & 1.62 & 0.11 & 0.92 & 0.14 \\
\hline \multicolumn{7}{|l|}{ Gonadotropins: } \\
\hline \multirow[t]{2}{*}{ FSH (IU/1) } & $\bar{x}$ & 7.92 & 8.43 & 30.13 & 31.34 & 27.31 \\
\hline & SD & 8.94 & 3.81 & 9.73 & 10.34 & 7.62 \\
\hline \multirow[t]{2}{*}{ LH (IU/1) } & $\bar{X}$ & 11.82 & 8.13 & 42.65 & 40.81 & 39.56 \\
\hline & SD & 6.91 & 5.62 & 10.11 & 13.83 & 16.51 \\
\hline \multirow[t]{2}{*}{ LTH $(\mathrm{ng} / \mathrm{ml})$} & $\overline{\mathrm{X}}$ & 26.31 & 22.56 & 25.54 & 31.36 & 23.79 \\
\hline & SD & 14.43 & 3.87 & 6.32 & 10.31 & 5.83 \\
\hline
\end{tabular}

$* \mathrm{p}<0.05$

** $\mathrm{p}<0.01$, exposed group versus control group

Table 3 presents the mean levels of some hematological findings among workers exposed to contraceptive drugs and their controls. Compared to controls the mean levels of hemoglobin among male workers and female workers manufacturing ampoules were significantly higher $(\mathrm{p}<0.05,0.01)$, but that of hematocrit was higher $(\mathrm{p}<0.01)$ only among females manufacturing ampoules. The mean levels of eosinophils were found to increase significantly $(p<0.05,0.01)$ among female workers of both groups. For the rest of the hematological findings, no statistically significant difference could be detected between exposed workers and control subjects.

The mean levels of prothrombin, bleeding and clotting times among workers exposed to contraceptive drugs and their controls are presented in Table 4. The mean levels of both prothrombin and bleeding times were found to be significantly higher $(p<0.05,0.01)$ among exposed workers either males or females when 
Table 3. Mean levels of some hematological findings among workers exposed to contraceptive drugs and their controls.

\begin{tabular}{|c|c|c|c|c|c|c|}
\hline & \multirow[b]{4}{*}{$\mathrm{n}=$} & \multicolumn{2}{|c|}{ Males } & \multicolumn{3}{|c|}{ Females } \\
\hline & & \multirow{3}{*}{$\begin{array}{l}\text { Exposed } \\
18\end{array}$} & \multirow{3}{*}{$\begin{array}{l}\text { Controls } \\
19\end{array}$} & \multicolumn{2}{|c|}{ Manufacturing } & \multirow{3}{*}{$\begin{array}{c}\text { Controls } \\
27\end{array}$} \\
\hline & & & & Pills & Ampoules & \\
\hline & & & & 22 & 34 & \\
\hline \multirow[t]{2}{*}{ Hemoglobin $(\mathrm{g} \%)$} & $\bar{X}$ & $13.2^{*}$ & 12.3 & 11.6 & $12.3 * *$ & 11.4 \\
\hline & $\mathrm{SD}$ & 0.8 & 1.2 & 1.1 & 0.6 & 1.2 \\
\hline \multirow[t]{2}{*}{ Hematocrit (\%) } & $\overline{\mathrm{X}}$ & 39.2 & 36.9 & 35.4 & $36.5^{*}$ & 34.2 \\
\hline & $\mathrm{SD}$ & 6.4 & 3.6 & 3.0 & 2.2 & 2.7 \\
\hline \multirow[t]{2}{*}{ WBCs $\left(10^{3} / \mathrm{cmm}\right)$} & $\overline{\mathrm{X}}$ & 4.9 & 5.3 & 5.4 & 5.4 & 5.4 \\
\hline & $\mathrm{SD}$ & 2.3 & 3.8 & 3.6 & 4.3 & 3.9 \\
\hline \multirow[t]{2}{*}{$\operatorname{RBCs}\left(10^{6} / \mathrm{cmm}\right)$} & $\bar{X}$ & 4.3 & 4.0 & 3.8 & 4.0 & 3.6 \\
\hline & $\mathrm{SD}$ & 1.1 & 0.4 & 1.2 & 1.3 & 0.7 \\
\hline \multirow[t]{2}{*}{ Neutrophils (\%) } & $\overline{\mathrm{X}}$ & 54.8 & 53.1 & 53.5 & 53.5 & 53.0 \\
\hline & $\mathrm{SD}$ & 13.8 & 6.3 & 3.8 & 3.9 & 4.5 \\
\hline \multirow[t]{2}{*}{ Lymphocytes (\%) } & $\bar{X}$ & 35.9 & 37.1 & 38.4 & 38.1 & 37.9 \\
\hline & $\mathrm{SD}$ & 3.3 & 2.2 & 2.4 & 2.4 & 2.3 \\
\hline \multirow[t]{2}{*}{ Eosinophils (\%) } & $\overline{\mathrm{X}}$ & 3.1 & 2.8 & $3.2 *$ & $3.6^{* *}$ & 2.4 \\
\hline & $\mathrm{SD}$ & 1.5 & 1.8 & 1.5 & 1.8 & 1.1 \\
\hline \multirow[t]{2}{*}{ Basophils (\%) } & $\overline{\mathrm{X}}$ & 0.3 & 0.3 & 0.2 & $0.1^{*}$ & 0.3 \\
\hline & $\mathrm{SD}$ & 0.4 & 0.5 & 0.4 & 0.3 & 0.4 \\
\hline \multirow[t]{2}{*}{ Monocytes (\%) } & $\bar{X}$ & 2.3 & 1.7 & 2.1 & 2.3 & 2.1 \\
\hline & SD & 1.9 & 1.4 & 1.9 & 1.9 & 1.9 \\
\hline
\end{tabular}

$* \mathrm{p}<0.05$

** $\mathrm{p}<0.01$, exposed group versus control group

compared to the control subjects. The mean levels of clotting time did not change significantly among exposed workers.

Table 5 shows the mean levels of FBS, ALT and AST activity and serum creatinine among workers exposed to contraceptive drugs and their controls. The mean levels of ALT activity increased significantly $(\mathrm{p}<0.01)$ among female workers while that of AST increased significantly $(\mathrm{p}<0.01)$ among male workers. Fe- 
Table 4. Mean levels of prothrombin, bleeding and clotting times among workers exposed to contraceptive drugs and their controls.

\begin{tabular}{|c|c|c|c|c|c|c|}
\hline & \multirow[b]{4}{*}{$\mathrm{n}=$} & \multicolumn{2}{|c|}{ Males } & \multicolumn{3}{|c|}{ Females } \\
\hline & & \multirow[t]{2}{*}{ Exposed } & \multirow[t]{2}{*}{ Controls } & \multicolumn{2}{|c|}{ Manufacturing } & \multirow{3}{*}{$\begin{array}{c}\text { Controls } \\
27\end{array}$} \\
\hline & & & & Pills & Ampoules & \\
\hline & & 18 & 19 & 22 & 34 & \\
\hline Prothrombin time & $\overline{\mathrm{X}}$ & $15.53^{*}$ & 12.88 & $16.54 * *$ & 16.37 & 13.26 \\
\hline$(\sec )$ & SD & 4.34 & 0.65 & 1.82 & 9.87 & 0.55 \\
\hline Bleeding time & $\bar{X}$ & $5.03^{* *}$ & 1.96 & $4.03 * *$ & $5.21 * *$ & 1.96 \\
\hline$(\min )$ & SD & 0.54 & 0.24 & 0.47 & 0.54 & 0.19 \\
\hline Clotting time & $\bar{X}$ & 5.16 & 4.92 & 5.34 & 4.72 & 5.08 \\
\hline$(\min )$ & SD & 1.11 & 0.71 & 1.91 & 0.79 & 0.71 \\
\hline
\end{tabular}

$* \mathrm{p}<0.05$

** $\mathrm{p}<0.01$, exposed group versus control group

Table 5. Mean levels of fasting blood sugar, transaminases activity and serum creatinine among workers exposed to contraceptive drugs and their controls.

\begin{tabular}{|c|c|c|c|c|c|c|}
\hline & \multirow[b]{4}{*}{$\mathrm{n}=$} & \multicolumn{2}{|c|}{ Males } & \multicolumn{3}{|c|}{ Females } \\
\hline & & \multirow[t]{2}{*}{ Exposed } & \multirow[t]{2}{*}{ Controls } & \multicolumn{2}{|c|}{ Manufacturing } & \multirow[t]{2}{*}{ Controls } \\
\hline & & & & Pills & Ampoules & \\
\hline & & 18 & 19 & 22 & 34 & 27 \\
\hline \multirow[t]{2}{*}{ FBS (mg/dl) } & $\bar{x}$ & 94.16 & 92.47 & 118.81 & 92.65 & 93.74 \\
\hline & SD & 38.82 & 22.86 & 61.56 & 21.37 & 35.65 \\
\hline \multirow[t]{2}{*}{ ALT (IU/l) } & $\bar{x}$ & 36.41 & 30.53 & $37.17 * *$ & $38.74 * *$ & 28.63 \\
\hline & $\mathrm{SD}$ & 18.87 & 5.86 & 11.83 & 14.68 & 8.47 \\
\hline \multirow[t]{2}{*}{ AST (IU/l) } & $\overline{\mathrm{X}}$ & $35.54 * *$ & 25.73 & 31.32 & 30.74 & 29.91 \\
\hline & SD & 5.89 & 7.36 & 11.75 & 14.21 & 9.38 \\
\hline \multirow[t]{2}{*}{ S. creatinine $(\mathrm{mg} / \mathrm{dl})$} & $\overline{\mathrm{X}}$ & 0.91 & 0.83 & 0.94 & $0.95 *$ & 0.79 \\
\hline & SD & 0.42 & 0.09 & 0.26 & 0.39 & 0.11 \\
\hline
\end{tabular}

$* \mathrm{p}<0.05$

$* * \mathrm{p}<0.01$, exposed group versus control group 
male workers manufacturing ampoules had statistically significant higher levels ( $\mathrm{p}$ $<0.01$ ) of serum creatinine when compared to their controls. The mean levels of FBS did not differ significantly between exposed workers and control subjects.

The mean levels of some blood lipids among workers exposed to contraceptive drugs and their controls are tabulated in Table 6. Comparison between exposed workers and control subjects revealed significant lower levels $(\mathrm{p}<0.01)$ of cholesterol and higher levels of HDLCh $(\mathrm{p}<0.01)$ among male workers and lower levels $(\mathrm{p}<0.01)$ of triglyceiides among female workers manufacturing ampoules. Concerning LDLCh, significant lower levels $(\mathrm{p}<0.01)$ were found among all groups of exposed workers.

Table 7 compares the mean levels of some trace elements in sera of workers exposed to contraceptive drugs and their controls. Statistically significant higher levels $(\mathrm{p}<0.05,0.01)$ of calcium and manganese were found among all workers exposed to contraceptive drugs. Higher mean levels of copper and zinc $(\mathrm{p}<0.05)$ were found among male workers and zinc only $(\mathrm{p}<0.05)$ among female workers manufacturing ampoules. No statistically significant changes have been observed among exposed workers in the mean levels of neither iron nor magnesium.

Table 6. Mean levels of some blood lipids among workers exposed to contraceptive drugs and their controls.

\begin{tabular}{|c|c|c|c|c|c|c|}
\hline & \multirow[b]{4}{*}{$\mathrm{n}=$} & \multicolumn{2}{|c|}{ Males } & \multicolumn{3}{|c|}{ Females } \\
\hline & & \multirow[t]{2}{*}{ Exposed } & \multirow[t]{2}{*}{ Controls } & \multicolumn{2}{|c|}{ Manufacturing } & \multirow[t]{2}{*}{ Controls } \\
\hline & & & & Pills & Ampoules & \\
\hline & & 18 & 19 & 22 & 34 & 27 \\
\hline \multirow[t]{2}{*}{ Cholesterol (mg/dl) } & $\bar{X}$ & $166.3 * *$ & 221.4 & 182.3 & 172.1 & 190.1 \\
\hline & SD & 36.9 & 25.2 & 58.2 & 48.3 & 33.1 \\
\hline \multirow[t]{2}{*}{ Triglycerides $(\mathrm{mg} / \mathrm{dl})$} & $\bar{X}$ & 139.7 & 137.5 & 144.3 & $133.3 * *$ & 157.5 \\
\hline & SD & 19.4 & 14.1 & 29.7 & 39.2 & 22.3 \\
\hline \multirow[t]{2}{*}{ HDL-Ch (mg/dl) } & $\bar{X}$ & $54.8^{* *}$ & 44.8 & 58.5 & 64.6 & 59.3 \\
\hline & SD & 12.7 & 15.4 & 22.1 & 20.2 & 21.2 \\
\hline \multirow[t]{2}{*}{ LDL-Ch (mg/dl) } & $\overline{\mathrm{X}}$ & $110.5 * *$ & 143.5 & $84.1 * *$ & $109.5 * *$ & 135.6 \\
\hline & $\mathrm{SD}$ & 15.4 & 7.3 & 19.5 & 34.3 & 28.7 \\
\hline
\end{tabular}

$* \mathrm{p}<0.05$

** $\mathrm{p}<0.01$, exposed group versus control group 
Table 7. Mean levels of some trace elements in serum of workers exposed to contraceptive drugs and their controls.

\begin{tabular}{|c|c|c|c|c|c|c|}
\hline & \multirow[b]{4}{*}{$\mathrm{n}=$} & \multicolumn{2}{|c|}{ Males } & \multicolumn{3}{|c|}{ Females } \\
\hline & & \multirow[t]{2}{*}{ Exposed } & \multirow[t]{2}{*}{ Controls } & \multicolumn{2}{|c|}{ Manufacturing } & \multirow{3}{*}{$\begin{array}{c}\text { Controls } \\
27\end{array}$} \\
\hline & & & & Pills & Ampoules & \\
\hline & & 18 & 19 & 22 & 34 & \\
\hline \multirow[t]{2}{*}{ Calcium (mg/dl) } & $\overline{\bar{X}}$ & $8.7 * *$ & 7.2 & $8.9^{*}$ & 8.6 & 7.9 \\
\hline & SD & 1.8 & 1.4 & 1.2 & 1.4 & 1.6 \\
\hline \multirow[t]{2}{*}{ Manganese $(\mu \mathrm{g} / \mathrm{dl})$} & $\bar{X}$ & $0.4^{* *}$ & 0.2 & $0.5 * *$ & $0.4^{* *}$ & 0.2 \\
\hline & $\mathrm{SD}$ & 0.2 & 0.2 & 0.3 & 0.1 & 0.2 \\
\hline \multirow[t]{2}{*}{ Iron $(\mu \mathrm{g} / \mathrm{dl})$} & $\bar{X}$ & 147.7 & 142.5 & 146.6 & 138.7 & 136.3 \\
\hline & SD & 30.2 & 16.6 & 24.1 & 15.9 & 16.2 \\
\hline \multirow[t]{2}{*}{ Copper $(\mu \mathrm{g} / \mathrm{dl})$} & $\bar{x}$ & $98.2^{*}$ & 81.9 & 102.6 & 93.3 & 96.9 \\
\hline & SD & 27.4 & 6.8 & 28.1 & 18.9 & 25.6 \\
\hline \multirow[t]{2}{*}{$\operatorname{Zinc}(\mu \mathrm{g} / \mathrm{dl})$} & $\bar{X}$ & $106.4 *$ & 93.3 & 91.6 & $105.8 *$ & 93.5 \\
\hline & $\mathrm{SD}$ & 20.6 & 17.9 & 21.6 & 18.5 & 19.5 \\
\hline \multirow[t]{2}{*}{ Magnesium (mg/dl) } & $\overline{\mathrm{X}}$ & 1.7 & 1.5 & 1.7 & 1.8 & 1.6 \\
\hline & SD & 0.3 & 0.5 & 0.4 & 0.4 & 0.6 \\
\hline
\end{tabular}

$* \mathrm{p}<0.05$

$* * \mathrm{p}<0.01$, exposed group versus control group

\section{Discussion}

In Egypt around $50 \%$ of women ever used pills for contraception ${ }^{8)}$. This wide use is accompanied by an important production. Though these products meet high standards, the question remains whether the safety of the production workers is sufficiently guaranteed

To minimize the effect of sex hormones intake for contraception, only post menopausal females were included. Therefore, female workers were older and had longer duration of exposure than males as shown in Table 1. Their mean age of menopause $(46.23 \pm 2.98$ years $)$ is not significantly different from the national one $(47.89 \pm 3.77)^{9)}$. Since the comparison between males and females is out of the scope of the present study, it seemed not necessary to include younger males.

Also, comparison between females manufacturing pills and those manufacturing ampoules is not reasonable since the latter group is more heavily exposed ${ }^{5}$. However, some effects especially the levels of estrogen in blood and the liver function tests were found to be similar between the three groups of exposed workers. This makes the importance of the duration and intensity of exposure to contraceptive drugs when assessing their health effects questionable. 
Concerning the selection of indices of exposure to contraceptive drugs, a simplified descriptive model ${ }^{10)}$ explains the choice of test components. The main organ in this model is the pituitary gland, whence are released various gonadotropins: LTH, FSH and LH. The peripheral organs are liver, testicles and ovaries. Accordingly, the plasma levels of sex hormones is the result of the activity of the endocrine nuclei of the hypothalamus that secretes gonadotropin releasing hormone and the liver and other tissues involved in sex hormones metabolism.

The sex hormones that have been affected by exposure to contraceptive drugs in the present study were estrogen and testosterone. Increased levels of estrogen in blood of male workers have been observed. Similar findings have been reported in literature ${ }^{1,5,11-13)}$. Total testosterone is known as an indicator of the functioning of testicles, but it can be converted to estrogen in tissues other than endocrine glands after exposure to estrogens ${ }^{10)}$. This might explain at least partially the increased levels of estrogen especially among males. Concerning the gonadotropins, several studies reported increased levels of $\mathrm{LTH}^{14)}$ and lower levels of both $\mathrm{LH}$ and $\mathrm{FSH}^{13-15)}$ among workers exposed to oral contraceptives. These parameters have not been affected in the present work, suggesting that tissues other than pituitary gland might be responsible for the observed hyperesterogenism. On the other hand, the present study proved that exposure to contraceptive drugs affected the liver functions of the exposed workers as they showed higher levels of ALT and AST, prolonged prothrombin time and increased concentrations of serum calcium and manganese. These parameters have always been of great importance for liver integrity evaluation ${ }^{17-19}$. Therefore it seems that the increased levels of blood estrogen resulted from the alteration in liver functions and not pituitary functions caused by exposure to contraceptive drugs. An explanation might be that some individuals are more sensitive to liver response to estrogens and/or for some estrogens liver may be the main target, in addition to the fact that the liver is a major organ for steroid metabolism and their substantial effects on hepatic metabolic pathways is to be expected ${ }^{20)}$.

Among other effects of contraceptive drugs exposure; the present study revealed some increase in the levels of hemoglobin, eosinophils, bleeding time, serum creatinine and fasting blood sugar. This increase usually reached the level of statistical significance. Some of these results are in agreement, other are contradicted by those found in literature. Acceleration of blood clotting tests ${ }^{21)}$, elevated ${ }^{22}$ and decreased ${ }^{23)}$ blood glucose levels after administration of oral contraception have been reported.

Concerning lipid metabolism, a less atherogenic lipid profile has been found among exposed workers. This included a lower deleterius LDLCh fraction and a higher cardioprotective HDLCh one. Again these findings are to be expected since contraceptives are used successfully to reverse the negative trends of lipid profile attributed to the decline in ovarian estrogen production as a consequence of menopause ${ }^{24-26)}$. Although these changes can be considered advantageous from 
the cardiovascular point of view, yet their clinical significance concerning other systems remains obscure.

In conclusion, the biochemical effects of occupational exposure to contraceptive drugs seem to be evident and anxiety must be expressed on the risk of developing not only neoplastic disease but also some organs dysfunction. It seems necessary to refer to the preventive measures for workers exposed to contraceptive drugs ${ }^{27)}$. Among these, adoption of a time-weighted average of $0.05 \mu \mathrm{g}$ airborne estrogen dust $/ \mathrm{m}^{3}$ and examination of persons directly involved in the hazardous sectors of manufacture every two weeks and those engaged in the pharmaceutical stage of manufacture monthly. Even the need for a closed system of the entire production process of contraceptive drugs can be suggested.

\section{REFERENCES}

1) Harrington J, Stein G, Rivera R, de Morales A. The occupational hazards of formulating oral contraceptives. A survey of plant employees. Arch Environ Health 1978; 33: 12-5.

2) Vessey M, Doll R, Peto R. A long-term follow up study of women using different methods of contraception. An interim report. J Biosoc Sci 1976; 8: 373-427.

3) Hickey R, Clelland R, Bowers E. Essential hormones as carinogenic hazards. J Occup Med 1974; 21: $265-8$.

4) Farina G, Alessio L, Bandral S. L'esposizione professionals a farmaci: Ormoni. Med Lav 1977; 68: $105-13$.

5) El Samra G, El Safty A, Siha M, Fathy A. Breast changes in workers engaged in the manufacture of sex hormones. Egypt J Occup Med 1992; 16: 237-44.

6) Sissin J. Handbook of clinical pathology. In: JB Lippincott G, eds. Philadelphia, 1976; 1728.

7) Shimadzu flame atomic absorption manual. Standard analytical methods; 1990.

8) Egypt. Maternal and child health survey 1991. Farouk Abdel Azeem Samir Farid, Atef Khallfa. Pan Arab Project for Child Development 1993: 152.

9) Bayoumi S, Ayoub A, Khamis Y, Sobhi S. Determination of menopausal age among females attending the outpatient gynecology clinic in Al Shatby Hospital. Tanta Med J I994; 22: 133749.

10) Willems H. Occupational exposure to estrogens and screening for health effects. J Occup Med 1981; 23: 813-6.

11) Gilman A, Goodman L, Gilman A. The pharmacological basis of therapeutics. In Boston G, eds. Mac Millan Publishing, 1980: 1450.

12) Robinson R, Higano N, Cohen W. Long-term effects of high-dose estrogen therapy in men with coronary heart disease. J Chronic Dis 1963; 16: 155-61.

13) Kulin H, Reiter E. Gonadotropin and testosterone measurement after estrogen administration to adult men, prepubertal and pubertal boys and men with hypogonadotropism. Evidence for maturation of positive feedback in the male. Pediatr Res 1976; 10: 46-51.

14) Franchimont P, Dourcy C, Legros J et al. Dosage de la prolactine dans les conditions nonnales et pathologiques. Ann Endocrinol (Paris) 1976; 37: 127-56.

15) Kulin H, Reiter E. Gonadotropin suppression by low dose estrogen in men: Evidence for differential effects upon FSH and LH. J Clin Endocrinol Metab 1972; 35: 836-9.

16) Walsh P, Swerdloff R, Odell W. Feedback control of FSH in the male the role of estrogen. Acta Endocrinol (Copenhgen) 1973; 74: 449-60.

17) Innerfield F. Enzymes in clinical chemistry. McGraw-Hill Publications, New York, 1960; 46571.

18) Tiez N. Fundamentals of clinical chemistry. 3rd ed. Philadelphia: W B Saunders, 1987; 2578. 
19) Fikry A. Gastroentrology. Part I. El Maaref Establishment, Alexandria, 1978; 106-8.

20) Kalkhoff R. Metabolic effects of progesterone. Am J Obstet Gynecol 1982; 142: 735-9.

21) Poller L, Thompson J, Otridge B, Yee K, Logan S. Effects of manufacturing oral contraceptives on blood clotting. British Med J 1979; 1: 1761-2.

22) Spellacy W. Carbohydrate metabolism during treatment with estrogen, progesterone and low dose oral contraceptives. Am J Obstet Gynecol 1982; 142: 732-7.

23) Seed M, Godalands I, Wynn V, Jacobs J. The effects of cyproterone acetate and ethinyl estradiol on carbohydrate metabolism. Clin Endocrin 1984; 21: 689-94.

24) Jensen J, Nilas L, Christiansen C. Influence of menopause on serum lipids and lipoproteins. Maturitas 1990; 12: 321-31.

25) Mathews K, Elaine M, Kuller I, Kelsey S, Cagguila A, Wing P. Menopausal and risk factors for coronary heart disease. N Engl J Med 1989; 321: 641-6.

26) Jensen J, Riis B, Storm V, Nilas I, Christiansen C. Longterm effects of percutanous estrogen and oral progesterone on serum lipoproteins in postmenopausal women. Am J Obstet Gynecol 1987; 156: 66-71.

27) Encyclopedia of occupational health and safety. International Labor Office. Geneva. 3rd revised ed. $1989 ; 1049-52$. 